first, the students in the affected faculties went on strike, hut they received little support from the professors and the public and eventually had to relent. The system has been extended to all parts of all universities this year.

In May 1996 the administration of the university system was decentralized. The three campuses became autonomous universities. The post of rector was abolished, and the vice rectors in charge of each campus became the presidents of the new establishments.New governing councils are also being created that will have stronger representation from nontraditional sectors in civil society.

In October 1996 the traditional faculties and the various institutes and research centers were abolished and replaced by a variety of structures - the primary one being the unité de formation et de recherché (UFR), in which almost all teaching and research will be based. The creation of new regional university centers (incipient universities) and continuing education centers will also be based in the universities. Already two new campuses in Daloa and Korhogo have been created under the administration of AboboAdjamé and Bouaké respectively.

The cynics saythat old wine is being put in new bottles. That is true to a certain extent. But renewing the vigor of the public system of higher education will not be easy without putting asunder the old structure- - someof which have become sinecures for people no longer activelyengaged in teaching and research. It remains to be seen if these measures can really restore quality and vitality.

However, the most important "reform"in higher education during the past decade has taken place outside the public system, almost hidden from sight. In response to the failure of the system to meet the new realities of the 1980 s, private schools emerged to give practical training to failed high school students who could not find work. The courses offered are what would appeal to private-sector employers: accounting and office systems technology (still called secretaryship here), public relations and communications, computer literacy, computer science, and electronics technology, resulting in a junior or senior high school diploma.

Over the past decade, these private institutions have also moved up to the tertiary level as high school graduates opted for programs in the same subject areas but leading to a Brevet de Technicien Supérieur (BTS), a diploma equivalent to the American AA/AS degree. In 1996, a third of the 1996high school graduates, 5,650 out of 16,041, asked the government to secure them a place in one of these schools rather than a university or grande école.

Why the change? Ivoirian students and their parents have finally understood that government is no longer a re- liable source of employment and that a university degree does not necessarily lead to employment in the private sector where the new jobs are emerging. The Ivoirian government has also recognized the usefulness of these private institutions and the education they offer. Therefore, it has worked out a system whereby it pays the difference between the university tuition (which is nominal) and the normal tuition fees of the institution that the student attends. The government now supports about $11,000 \mathrm{stu}-$ dents in BTS-level programs in private schools. Therefore, it is an effective subsidy to these institutions that gives them a financial security and allows them to develop more programs.

Is privatization the wave of the future for higher education in the Cote d'Ivoire? For technical and commercial education it has already happened. Will private universities be created? It remains to be seen, hut it has already happened in other parts of West Africa.

\section{Assistance for African Higher Education: \\ The Association for the Development of African Education (DAE)}

\section{William Saint}

William Saint is senior educational specialist, Population and Humon Resources, Westand Central Africa Region, The World Bank, Washington D.C. For further information, please contact Teresa Hartneft, AFTHR, The World Bank, 1818 H Street, N.W., Worhington, D.C. Emoil: THARTNET@WORLDBANK.ORG.

A frican universities are struggling to emerge from a decade of crisis characterized by rapid growth, ansustainable financial arrangements, heavy staff losses, frequent labor unrest and campus closures, institutional deterioration, waning relevance, and declining educational quality. In numerous countries, university graduates are less capable and less qualified today than they were 10 years ago, and university research output has almost ceased. As a result, many African universities produce neither the skilled human resources nor the new knowledge necessary to guide. national development in the years ahead. At risk is nothing less than the region's future capacity to manage its own affairs at an acceptable standard.

Responding to this challenge, 40 bilateral, multilateral, and private donor agencies from Europe and North America have launched a bold experiment in interagency coordination. To increase the effectiveness of their assistance to the education sector in sub-Saharan Africa, they 
have formed a loose consortium intended to facilitate information exchange, glean guidance from the lessons of their collective aid experience, and improve the impact of their development funding through more informed and coordinated action. This consortium, known as the Association for the Development of African Education (DAE), has evolved into a significant forum for dialogue between donor agency representatives and African education leadership on the priorities and modalities for human resource development on the continent.

The work of the DAE is carried out in a dozen working groups formed around key educational themes. Each working group is managed separately by a lead donor agency that serves as coordinator and convener of the group. The DAE is supported by a small secretariat that issues a newsletter, maintains a database on some 1,100 donor projects supporting African education, and organizes the annual meetings. This secretariat initially operated out of the World Bank, hut has now been established as a more autonomous and donor-accountable office under the auspices of the International Institute for Educational Planning in Paris.

Among the working groups, the Working Group on Higher-Education (WGHE) has attracted increasing attention and participation as a result of its constructive focus on complex tertiary education issues that concern donors, governments, and university leaders alike. This interest reflects growing recognition that African universities contribute significantly to education sector development and national capacity building on the continent. Universities set the standard for primary and secondary education, training teachers, administrators, researchers, and policymakers in the education field. Universities are also the principal source of the skilled leadership and technical expertise needed to guide national development. University-trained human resources, together with the research and policy analyses they produce, constitute fundamental inputs for national capacity building.

W GHE has established itself as a forum for the exchange of information, experience, and ideas among donor agency staff and higher education leadership in Africa. A growing number of a genciesn ow some 15-have been regularly represented at WGHE meetings. Half a dozen agencies have contributed studies for discussion or helped to finance analyses commissioned by WGHE. To date, 18 different reports have been published and distributed. In the process, WGHE has become a recognized advocacy resource on African higher education.

WGHE, which is coordinated by a World Bank staff member, has held nine meetings to date, all in Africa. The
Association of African Universities (AAU) has regularly participated, together with a significant number of invited African university leaders and experts. These meetings, initially cohosted by locally based donor agencies, have later been organized in collaboration with specific universities. Since 1993, the AAU has held consultative meetings with donors in conjunction with W GHE meetings. In this way, the W GHE is developing into a nimportant regular forum for cooperation in African higher education.

Over the longer term, it is anticipated that these efforts will contribute to greater quality and relevance of university education and research in many African higher education systems. Three intermediate steps are necessary to produce these results. First and foremost, progressive gains in the stability and sustainability of higher education financing throughout the region must be pursued. At the same time, greater effectiveness in the management of human and financial resources within African universities is needed in order to maximize the benefits from these scarce inputs. Finally, greater consistency and long-term vision in donor and governmental support programs for African universities will he required for the institutional transformations and developments necessary to keep African centers of higher learning on a par with their sister institutions on other continents.

Special Publication Note

A limited number of pre-publication copies of The International Academic Profession: Portraits from Fourteen Conntries, edited by Philip G. Altbach (with anintroduction by Ernest L. Boyer), arc available from the Center for International Higher Education. This 750-page paperback book has been produced by the Center mainly for classroom use, but copies are available on a limited basis. $\mathrm{T}$ h $\mathrm{e}$ regular edition will be published later in 1997 by the Carnegie Foundation for the Advancement of Teaching, which sponsored the book and the study on which it is based. This book features essays on the attitudes and values of the professoriate in the 14 countries that participated in the firstinternational study of the academic profession. The counmes include Australia, South Korea,Japan, Hong Kong, Brazil, Chile, Mexico, the United States, Germany, the Netherlands, Sweden, Russia,England, and Israel. Copies may be ordered directly from the Center. The price is $\$ 15$ postpaid (add $\$ 5$ for postage outside of North America). Checks must be made out to Boston College and must be drawn on US. banks. Only prepaid orders can be accepted. 